\title{
Gambaran Karakteristik Pengetahuan, Sikap dan Perilaku Risiko Covid-19 Dalam Kerangka Desa Adat di Desa Gulingan, Mengwi, Bali
}

Agus Indra Yudhistira Diva Putra ${ }^{1}$, Made Sindy Astri Pratiwi ${ }^{1}$, Made Violin Weda Yani ${ }^{1}$, Gufran Rizaldy Danang Gunawan $^{2}$, Ghaniy Muhammad Ganesha ${ }^{3}$, Agnes Maria Aprilia Evelyn Aminawati ${ }^{4}$ I Putu Gede Dharma Wibhawa Aryana $^{5}$, I Gusti Agung Alit Suryawati ${ }^{6}$

\begin{abstract}
Abstrak
Desa Gulingan adalah salah satu desa adat di Kecamatan Mengwi yang merupakan peringkat pertama kecamatan dengan kasus tertinggi Covid-19 di Kabupaten Badung sangat berpeluang mengalami peningkatan kasus akibat transmisi lokal. Berdasarkan hal tersebut hingga saat ini belum terdapat hasil deskriptif yang mengkaji pengetahuan, sikap, dan perilaku masyarakat Desa Gulingan dengan sistem sosial kemasyarakatannya yang berbasis budaya dalam kerangka desa adat. Tujuan: Mengetahui gambaran tentang pengetahuan, perilaku, perilaku beresiko Covid-19 pada masyarakat Desa Gulingan dalam kerangka desa adat. Metode: Ini adalah penelitian deskriptif dengan rancangan studi potong lintang dengan jumlah sampel yang memenuhi kriteria inklusi dan eksklusi sebanyak 144 sampel. Hasil kuesioner disajikan dalam bentuk numerik dan kategorik dan selanjutnya dilakukan proses analisis secara univariat dalam variabel. Hasil: Responden penelitian didominasi oleh laki-laki $(55,3 \%)$, berstatus pendidikan SMA/sederajat $(62,3 \%)$, status pekerjaan terbanyak adalah pegawai swasta $(42,1 \%)$, sampel terbanyak diperoleh dari Banjar Angkeb Canging (20, 2\%). Hasil kuesioner yang berpengetahuan baik (51,8\%) berperilaku baik $(66,7 \%)$, dan terbukti/berpraktik baik $(56,1 \%)$ dalam pencegahan Covid-19. Simpulan: Pengetahuan, perilaku, dan sikap pada masyarakat Desa Gulingan yang baik dalam pencegahan virus corona dengan menerapkan kearifan lokal yakni dalam kerangka desa adat di Bali.
\end{abstract}

Kata kunci: covid-19, desa Gulingan, pengetahuan, perilaku, sikap

\section{Abstract}

Gulingan Village is a traditional village in Mengwi District, which is in the first rank of the sub-district with the highest case of Covid-19 in Badung Regency, has the potential for an increase in cases every day due to local transmission. Until now, there has been no result descriptive study that examines the knowledge, attitudes, and behavior of the people of Gulingan Village with their cultural-based social system within the framework of customary villages. Objectives: To described the characteristics of the knowledge, attitudes, and risk behavior of Covid-19 in the Gulingan Village community within the framework of a customary village. Methods: This was a descriptive study with a cross-sectional study design on 144 samples that met the inclusion and exclusion criteria. The results of the questionnaire are presented in numerical and categorical form and then the univariate analysis process is carried out in the variables. Result: The respondents were dominated by men (55.3\%), with senior high school/equivalent education status (62.3\%), the most occupational status was private employees $(42.1 \%)$, the largest sample was obtained from Banjar Angkeb Canging (20.2\%). The results of the questionnaire showed that the majority had good knowledge (51.8\%) of good behavior (66.7\%), and had good attitudes/ practices (56.1\%) in preventing Covid-19. Conclusion: The knowledge, behavior and attitudes of the majority of Gulingan Village residents are good in preventing the coronavirus by applying local wisdom, namely in the framework of traditional villages in Bali.

Keywords: covid-19, Gulingan village, knowledge, attitudes, behavior 
Affiliasi penulis: ${ }^{1}$ Program Studi Sarjana Kedokteran dan Profesi Dokter, Fakultas Kedokteran, Universitas Udayana, Denpasar, Indonesia. ${ }^{2}$ Program Studi Agribisnis, Fakultas Pertanian, Universitas Udayana, Denpasar, Indonesia. ${ }^{3}$ Program Studi Teknik Pertanian, Fakultas Pertanian, Universitas Udayana, Denpasar, Indonesia. ${ }^{4}$ Program Studi IImu Hukum, Fakultas Hukum, Universitas Udayana, Denpasar, Indonesia. ${ }^{5}$ Program Studi Sastra Jawa Kuna, Fakultas IImu Budaya, Universitas Udayana, Denpasar, Indonesia. ${ }^{6}$ Departemen IImu Komunikasi, Fakultas IImu Sosial dan IImu Politik, Universitas Udayana, Denpasar, Indonesia

Korespondensi: Agus Indra Yudhistira Diva Putra, Email; indrayudhistirawin@gmail.com Telp: 085739979936

\section{PENDAHULUAN}

Novel corona virus merupakan penyakit infeksi yang bermula dari Kota Wuhan, Provinsi Hubei, Tiongkok pada akhir Desember 2019 yang penyebarannya melalui transmisi udara atau yang dikenal dengan airborne disease. Penyakit ini merupakan new emerging disease yang merupakan varian baru dari penyakit saluran nafas atas yang belum pernah ditemukan sebelumnya dan terus menyebar keseluruh dunia menjadi kagawadaruratan global dan akhirnya masuk menuju ke Indonesia. ${ }^{1}$

Virus yang berjenis RNA ini memiliki gejala yang lebih berat dibandingkan dengan MERS dan SARS yang merupakan penyakit inflamasi pernafasan akut. Gejala penyakit ini antara lain adalah batuk, demam, lelah gelisah, dan laju respirasi menurun bila diukur dengan spirometri. ${ }^{2}$ Keadaan tersebut bila tidak diketahui oleh penderita akibat pengetahuan yang minimal dan tingkat pendidikan yang rendah sehingga akan membuat menurunnya kualitas hidup penderita yang berdampak mengancam nyawa (life treathening) apabila penderita merupakan usia tua dan memiliki komorbid penyakit kronik progresif berupa autoimun disease, hipertensi dan diabetes melitus yang memicu kondisi imunokompresi dan ditambah adanya badai sitokin atau cytocine storm ${ }^{3}$

Penyakit infeksi corona virus juga memiliki tiga mekanisme penularan yakni sesuai keadaan host, virulensi, dan environmental. Host diartikan sebagai kemampuan sistem imun yang terjadi pada tubuh setiap individu, semakin lemah dan termasuk dalam kelompok rentan maka penularan di komunitas akan tinggi. Virulensi merupakan keadaan materi genetik virus berubah manjadi subjenis berbeda dari sebelumnya. Segi environmental dimaksudkan sebagai keadaan berisiko untuk terjadi perpindahan penyakit seperti kontak langsung dengan penderita, mengonsumsi makanan dari intermediet host atau yang terkontaminasi dari penderita. ${ }^{4}$ Sehingga diperlukan tatalaksana non-pharmaeutical supaya dapat meningkatkan kesadaran masyarakat. ${ }^{5}$

Bali sebagai salah satu pintu gerbang pariwisata di Indonesia sangat rentan mengalami penambahan kasus corona virus bagi komunitas tertentu dalam masyarakatnya. Berdasarkan data yang dihimpun pertanggal 10 September 2020, Bali menduduki peringkat pertama tertinggi di Indoensia dengan trend kenaikan lebih dari $100 \%$ dari kasus sebelumnya dan melebihi kenaikan Jakarta sebagai Kota dengan populasi padat. $^{6}$ Kasus konfirmasi pertama SARSCoV2 terjadi di Kota Denpasar, ibu kota Provinsi Bali yang dibawa oleh wisatawan asing yang merupakan kejadian luar biasa pada saat itu. Terkait berkembangnya mobilisasi individu akibat antar kabupaten/kota menjadikan kabupaten terdekat yakni Badung menduduki peringkat kedua terbanyak kasus corona virus di Bali. ${ }^{7}$

Vaksin yang belum untuk kasus SARS-CoV-2, maka diperlukan suatu kesadaran pada masyarakat itu sendiri yang dimulai dari tingkat kota hingga ke desa agar memahami serta mengerti penyakit Covid-19 ini secara baik. Proses pencegahan dapat dilakukan dengan cara membuat ketahanan dari keluarga agar tangguh dalam pencegahan SARS-CoV-2. ${ }^{8}$

\section{METODE}

Penelitian ini menggunakan design study potong lintang yang telah dilakukan selama lima bulan mulai dari bulan Juli 2020 pada masyarakat Desa Adat Gulingan yang termasuk dalam tujuh banjar/dusun utama. Berdasarkan perhitungan rumus minimal partisipan yang diperlukan dalam penelitian ini adalah 53 orang dan hingga penelitian berakhir didapatkan 144 subjek yang memenuhi kriteria menjadi sampel. Cara pemilihan sampel pada penelitian ini adalah dengan simple randomized sampling yakni seluruh subjek yang sudah memenuhi kriteria inklusi dan eksklusi. Subjek wajib terdaftar di salah satu banjar di Desa Gulingan (menjadi penduduk), mampu membaca dan menulis, serta bersedia ikut penelitian setelah membaca informed consent. 
Pengambilan data dilakukan dengan menggunakan kuesioner kertas yang mendapatkan persetujuan dari Ketua/Kelihan Banjar dan nantinya sebelum memulai pengisian kuesioner akan dibagikan kepada pewakilan keluarga berdasarkan administrasi wilayah kependudukan (tempekan) untuk diiisi di Balai Banjar dalam kegiatan bersih banjar yang selanjutnya dilakukan proses pengisian informed consent penelitian yang artinya calon responden setuju ikut serta dalam penelitian. Setiap peserta harus memenuhi syarat protokol kesehatan berupa mencuci tangan menggunakan sabun/handsenetizer yang telah disediakan, menggunakan masker medis, jaga jarak, dan pengecekan suhu sebelum mengisi kuesioner di Balai Banjar. Setelah mengisi kuesioner, responden cukup menaruh di keranjang yang telah disediakan dan pulang secara kolektif. Tujuannya adalah untuk meminimalisir penyebaran penyakit dan kontak antara peneliti dengan masyarakat.

Pada kuesioner yang disebarkan merupakan kuesioner yang menggunakan Bahasa Indonesia dalam pertanyaannya yang berisi tentang karakteristik sosio-demografi masyarakat responden penelitian, pertanyaan yang mencangkup pengetahuan tentang Covid-19, perilaku mencegah penyebaran Covid-19 dan sikap (aktualisasi praktek) dalam kehidupan sehari-sehari dalam menerapkan protokol Kesehatan.

Kuesioner yang digunakan merupakan kuesioner yang diadaptasi dari penelitian yang telah dilakukan di Wuhan Tiongkok oleh Zhang et al (2020). Kuesioner yang berbahasa Inggris ini kemudian dilakukan penyesuaian dalam pertanyaan sehingga mudah dipahami menggunakan Bahasa Indonesia untuk mengukur pengetahuan, perilaku, sikap (aktualisasi praktek) masyarakat Desa Adat Gulingan terhadap Covid-19. ${ }^{9}$ Dalam setiap kategori dilakukan penjumlahan skor. Skor tinggi menunjukkan tingkat pengetahuan, sikap, dan perilaku yang lebih baik dibandingkan skor lebih rendah. Hasil skor dikategorikan menjadi dua bagian yakni baik dan buruk berdasarkan pemprosesan data yang dilakukan secara komputerisasi.

Penelitian deskriptif yang menggunakan data karakteristik sosio-demografi berupa identitas, riwayat medis dan penyakit respoden serta beberapa pertanyaan yang berkaitan dengan pengetahuan, perilaku, dan aktualisasi praktek terhadap Covid-19. Data akan disajikan dalam bentuk tabel dengan penyajian frekuensi dalam (n) dan persentase dalam persen (\%) sebagai variabel kategori.

Pertanyaan terdiri dari 4 subkategori yakni 11 pertanyaan yang berkaitan dengan karakteristik sosiodemografi pasien, 8 pertanyaan yang berkaitan dengan pengetahuan dasar responden terhadap Covid-19, 4 pertanyaan mengenai perilaku berisiko dilakukan responden selama pandemi dan 4 pertanyaan berkaitan dengan sikap atau aktualisasi responden selama pandemik. Nilai 0 untuk pilihan jawaban $A$ dan nilai tertinggi yakni 5 pada pilihan $F$. Sehingga urutan jawaban menggunakan urutan dalam skala linkert yang masing-masing pertanyaan terdiri dari enam pilihan dari pilihan sangat tidak setuju, tidak setuju, kadang setuju, setuju dan sangat setuju. Semakin tinggi skor menunjukkan awareness responden terhadap Covid-19.

Penelitian ini telah disetujui "laik etik" melalui Komisi Etik Penelitian, Fakultas Kedokteran Universitas Udayana/RSUP Sanglah dengan nomor: 1853/UN14.2.2.VII.14/LT/2020.

\section{HASIL}

Ada 114 responden melakukan pengisian kuesioner yang tersebar dalam tujuh banjar/dusun di Lingkungan Desa Adat Gulingan, Kecamatan Mengwi, Kabupaten Badung, Bali. Tabel 1 menunjukkan karakteristik sosio-demografi responden yang berpartisipasi dalam penelitian. 
Tabel 1. Karakteristik sosio-demografi

\begin{tabular}{|c|c|c|}
\hline Keterangan & $\begin{array}{c}\text { Frekuensi } \\
\text { sampel }(n=114)\end{array}$ & $(\%)$ \\
\hline \multicolumn{3}{|l|}{ Usia Pasien } \\
\hline Rerata $\pm S D$ & $36.46 \pm 15.15$ & \\
\hline Minimum & 10 & \\
\hline Maksimum & 75 & \\
\hline \multicolumn{3}{|l|}{ Jenis Kelamin } \\
\hline Laki-laki & 63 & 55.3 \\
\hline Perempuan & 51 & 44.7 \\
\hline \multicolumn{3}{|c|}{ Pendidikan terakhir } \\
\hline SD & 9 & 7.9 \\
\hline SMP & 7 & 6.1 \\
\hline SMA & 71 & 62.3 \\
\hline Diploma & 9 & 7.9 \\
\hline Sarjana & 18 & 15.8 \\
\hline \multicolumn{3}{|l|}{ Pekerjaan } \\
\hline Siswa & 21 & 18.4 \\
\hline \multicolumn{3}{|l|}{ /Mahasiswa } \\
\hline PNS & 5 & 4.4 \\
\hline Pegawai Swasta & 48 & 42.1 \\
\hline Petani & 6 & 5.3 \\
\hline Pedagang & 11 & 9.6 \\
\hline Lain-lain & 23 & 20.2 \\
\hline \multicolumn{3}{|l|}{ Banjar/Dusun } \\
\hline Batu lumbung & 17 & 14.9 \\
\hline Sedahan & 16 & 14.0 \\
\hline Munggu & 15 & 13.2 \\
\hline Badung & 20 & 17.5 \\
\hline Lebah Sari & 17 & 14.9 \\
\hline Angkeb Canging & 23 & 20.2 \\
\hline Dharmayasa & 6 & 5.3 \\
\hline
\end{tabular}

Sebanyak 63 orang $(55,3 \%)$ merupakan laki-laki. Karakteristik usia responden memiliki nilai rerata standar deviasi $36.46 \pm 15.15$ dengan rentang usia maksimum 75 tahun dan usia minimun 10 tahun. Sebagian besar responden memiliki status pendidikan terakhir SMA. Sebanyak 71 orang (62,3\%), 18 orang $(15,8 \%)$ sarjana dan 9 orang $(7,9 \%)$ orang merupakan diploma. Sisanya merupakan lulusan SD dan SMP sebanyak 9 dan 7 orang $(7,9 \%$ dan $6,1 \%)$. Berdasarkan pekerjaan saat ini mayoritas responden penelitian merupakan pegawai swasta sebanyak 48 orang $(42,1 \%)$ serta terbanyak kedua adalah lain-lain yang tidak termasuk dalam perkerjaan yang tersedia yakni sebanyak 23 orang $(20,2 \%)$. Semua partisipan atau responden penelitian mengklaim dirinya mengetahui dan pernah mendengar informasi berkaitan dengan Covid-19. Responden penelitian terbanyak berasal dari Banjar Angkeb Canging yakni sebesar 23 orang (20.2\%) dan tidak selisih jauh dengan Banjar Badung yakni sebanyak 20 orang (17.5\%).

Berdasarkan Tabel 2, maka hasil dari pengetahuan yang terdiri dari 8 soal tanda dan gejala (manifestasi klinis) pasien, tata cara pencegahan Covid-19 dapat diklasifikasikan sebagian besar partisipan responden memiliki pengetahuan baik terhadap Covid-19 yakni sebanyak 59 orang $(51,8 \%)$. Namun hasil tersebut hanya memiliki selisih sedikit dengan tingkat pengetahuan masyarakat yang buruk terhadap Covid-19 di Desa Gulingan sebanyak 55 orang $(48,2 \%)$.

Berdasarkan perilaku yang mengukur tingkat kerentanan responden terhadap infeksi corona virus yakni sebagian besar partisipan memiliki perilaku yang baik sebanyak 76 orang $(66,7 \%)$ dan hanya 38 orang yang memiliki perilaku yang buruk (33,3\%). Aktualisasi atau sikap dalam hal tindakan preventif sehari-hari yang dilakukan oleh partisipan untuk mengurangi pencegahan Covid-19 ini adalah sebagian besar partisipan memiliki aktualisasi praktek yang baik sebesar 64 orang $(56,1 \%)$ dan terjadi selisih sedikit berupa partisipan yang melakukan sikap/aktualisasi praktek buruk dalam pencegahan Covid-19 dalam sehari-hari yakni sebanyak 50 orang (43,9\%).

Tabel 2. Pengetahuan, sikap, dan perilaku risiko Covid-19

\begin{tabular}{lcc}
\hline Keterangan & $\begin{array}{c}\text { Frekuensi } \\
\text { sampel }(\mathbf{n = 1 1 4})\end{array}$ & $(\%)$ \\
\hline Tingkat & 59 & 51.8 \\
Pengetahuan & 55 & 48.2 \\
Baik & & \\
Buruk & 76 & 66.7 \\
Perilaku & 38 & 33.3 \\
Baik & & \\
Buruk & & \\
Aktualisasi Praktek & 64 & 56.1 \\
Baik & 50 & 43.9 \\
Buruk & & \\
\hline
\end{tabular}

\section{PEMBAHASAN}

Novel corona virus yang diidentifikasi sebagai pandemi global yang berasal dari Wuhan, Tiongkok yang sudah menyebar ke ratusan negara diseluruh dunia, salah satunya Indonesia. Indonesia sebagai 
negara yang memiliki penduduk terbesar di Kawasan

Regional Asia Tenggara tentu akan rentan mengalami kejadian kasus tertinggi dibandingkan negara lainnya di Asia Tenggara. Indonesia dengan sistem otonomi daerah yang dimiliki sebagai proses tatacara administrasi untuk mengatur masyarakat didalamnya berkewajiban menjaminkan kesehatan dan meminimalisir meningkatnya konfirmasi angka positif akibat Covid-19 sesuai dengan kebiasaan dan potensi daerah. ${ }^{10}$

Sebagai bentuk tantangan global maka diperlukan tindakan untuk mencegah penyebaran virus dengan melihat pengetahuan, perilaku, dan sikap masyarakat terhadap corona virus berdasarkan keterjangkauan akses informasi dari daerah desa hingga ke kota sehingga tatalaksana dari pihak desa melalui satuan tugas yang dibangun dapat bekerja maksimal dalam mengedukasi informasi Covid-19. ${ }^{11}$

Berdasarkan hasil penelitian ini didapatkan hasil sebagian besar 59 orang $(51,8 \%)$ memiliki pengetahuan yang positif tentang Covid-19 sebagai modal dasar mencegah infeksi virus dan transmisi human to human contact akibat droplet dan airborne.

Positifnya pengetahuan sangat berkorelasi langsung dengan tingkat Pendidikan. Hal itu sejalan dengan penelitian yang dilakukan di Bangladesh responden yang menjadi sampel mayoritas merupakan lulusan Pendidikan akhir SMA yang sudah mampu menyerap informasi berkaitan dengan Covid19. ${ }^{12}$ Terdapat beberapa penelitian yang bertolak belakang, seperti yang didapatkan pada penelitian di Malaysia menyatakan bahwa pengetahuan Covid-19 yang buruk dominan terjadi pada responden dengan berpenghasilan rendah. ${ }^{13} \mathrm{Hal}$ tersebut berpengaruh dari jumlah pekerja pada responden yang dominan pegawai swasta yang rentan dalam penerimaan informasi yang tidak adekuat sebagai salah satu faktor risiko yang rentan mengalami infeksi Covid-19. ${ }^{14}$ Keadaan tersebut dapat mengakibatkan perbedaan variasi informasi yang diterima dan sulit membedakan informasi benar dan tidak benar akibat beban frekuensi pekerjaan dan meningkatkan ambang kelelahan sehingga cenderung langsung menerima informasi tanpa menyaringnya atau diistilahkan information obesity. ${ }^{15}$ Pengaruh lain adalah kemampuan memahami literatur kesehatan dan paparan informasi berkaitan dengan promosi kesehatan. $^{16}$

Responden penelitian ini didapatkan perilaku baik yang dominan yakni sebanyak 76 orang $(66,7 \%)$. Sangat terpaut jauh dengan perilaku buruk atau tidak aware. Hasil ini juga sesuai dengan penelitian di Malaysia mendapatkan hasil bahwa Pemerintah Malaysia dapat mengurangi perilaku berisiko masyarakat untuk terkena Covid-19. ${ }^{17}$ Hal ini juga sesuai dengan penelitian yang dilakukan di Tiongkok berupa perilaku baik lebih ditunjukkan dalam hasil penelitian akibat peningkatan kasus kejadian yang memicu kesadaran diri timbul pada masyarakat. ${ }^{18}$ Berdasarkan hasil penelitian didapatkan hasil 64 orang $(56,1 \%)$ memiliki sikap baik, hal tersebut dilihat penggunaan pelindung diri pada kehidupan sehari-hari jaga jarak, menggunakan masker yang benar hingga menutupi hidung dan meninimalisir kontak kepada sesama. $^{19}$

Tradisi masyarakat lokal (local wisdom) berupa kegiatan gotong royong dalam kebersamaan (menyamabraya) sangat nihil untuk tidak dilakukan, maka perilaku ini terutama mencuci tangan, pakai masker, dan jaga jarak merupakan poin terpenting agar selalu diingat dan diterapkan. Salah satu penerapan jaga jarak adalah mengadakan pembagian kehadiran kegiatan dalam bentuk rentang waktu berdasarkan hitungan kepala keluarga (tempekan) untuk mengurangi transmisi lokal dan kerumunan. ${ }^{20}$

Hasil penelitian ini masih menunjukkan bahwa masih terdapat masyarakat yang memiliki sikap yang buruk yakni sebanyak 50 orang (43,9\%) yang cenderung tidak tepat dan salah mengartikan pandemi serta menggunakan pelindung diri tidak tepat seperti menggunakan masker hanya dimulut, berbicara membuka masker, menerima teman dengan bersalaman, dan jarang mencuci tangan setelah kontak dengan permukaan benda. ${ }^{21}$

Sebagian besar responden memiliki sikap baik dan optimis bisa melewati pandemi Covid-19 sebesar 64 orang $(43,9 \%)$. Hal tersebut merupakan bentuk kepercayaan masyarakat masih ada terhadap pemerintah sebagai pengatur regulasi dan kebijakan. Pada isian kuesioner dijelaskan bahwa beberapa responden masih ada yang ragu terhadap sikapnya dan masih megekspresikan negative emotions seperti 
kecemasan berlebih, panik, stress yang berpengaruh sekali terhadap perubahan perilaku responden. ${ }^{22}$

Tindakan tersebut perlu dipahami oleh SATGAS (satuan gugus tugas) penanggulangan Covid-19 Desa Adat dan Kabupaten Badung untuk meminimalkan kondisi negative emotions melalui pendekatan intrapersonal karena sikap sangat mempengaruhi besar perubahan perilaku kesehatan warga terhadap pandemi. ${ }^{23}$

Patofisiologi dari SARS-CoV-2 merupakan varian virus baru dan lebih berbahaya dibandingkan virus MERS dan SARS berdasarkan hasil penelitian ini menunjukkan laki-laki cenderung lebih kecil mengambil tindakan pencegahan dan perlindungan dibandingkan wanita. Data distribusi menunjukkan jumlah jenis kelamin pria yang banyak ikut serta dalam penelitian yakni sebanyak 63 orang (55,3\%). Atas dasar temuan ini awareness laki-laki dapat ditingkatkan dengan membuat program kesehatan yang menyasar dan fokus ditujukan untuk laki-laki saja melalui alih tukar informasi dalam keluarga baik dari istri maupun anak sehingga dapat mempengaruhi tatacara perilaku dan pandangan laki-laki terhadap pandemi Covid-19. ${ }^{24}$

\section{SIMPULAN}

Secara garis besar Desa Adat Gulingan sudah mampu memberikan informasi mengenai Covid-19 kepada warganya, namun terdapat beberapa permasalahan untuk dapat menurunkan persepsi masyarakat yang masih memiliki pengetahuan, perilaku, dan sikap yang negatif/buruk karena berdasarkan studi ini selisih antara pembanding baik dan buruk sangat tipis. Diharapkan kedepan mampu memilih program dengan pendekatan intra-personal agar setiap individu menjadi sadar dan tanggap terhadap COVID-19 sehingga menciptakan desa adat tangguh COVID-19 yang makin baik.

\section{UCAPAN TERIMA KASIH}

Terimakasih kepada seluruh pihak yang terlibat dalam terselenggaranya penelitian ini. Kepala Desa Gulingan, Kelian Banjar di Desa Gulingan, seluruh masyarakat di Desa Gulingan yang berpatisipasi dalam penelitian ini. Besar harapan penelitian ini dapat menjadi rekomendasi penulis lain untuk membuat penelitian lanjutan

\section{DAFTAR PUSTAKA}

1. Shigemura J, Ursano RJ, Morganstein JC, Kurosawa M, Benedek DM. Public Response to the novel 2019 coronavirus (2019-nCoV) in Japan: Mental health consequences and target populations. Wiley Online Library Journal. 2020;74(4):1-6

2. Huang $C$, Wang $Y, L i \quad X$. Clinical features of patients infected with 2019 novel coronavirus in Wuhan China. The Lancet. 2020; 395 (10223): 497-506.

3. Li JY, You Z, Wang Q. Zhou ZJ, Qiu Y, Luo R, Ge $X Y$. The epidemic of 2019-novel-coronavirus (2019-nCoV) pneumonia andinsights for emerging infectious diseases in the future. Journal Microbes and Infection. 2020;22(2):80-5.

4. Eslami $H$, Jalili $M$. The role of environmental factors to transmission of SARS-CoV-2 (COVID19). AMB Expr. 2020;10(92).

5. Guo YR, Cao QD, Hong ZS, Tan YY, Chen SD, Jin, HJ, et al. The origin, transmission and clinical therapies on coronavirus disease 2019 (Covid-19) outbreak-an update on the status. Military Medical Research. 2020;7(11):1-10.

6. Pemerintah Provinsi Bali. Data sebaran kasus Covid-19 sampai dengan tanggal 18-07-2020 di Bali. (serial online), [diakses 10 September 2020]. Tersedia dari: https://pendataan.baliprov.go.id/

7. Dinas Kesehatan Pemerintah Provinsi Bali. Kasus Perkabupaten di Bali 2020 [diakses 8 september 2020]. Tersedia dari: https://www.diskes. baliprov.go.id/portfolio/perkembangan-penyebaranvirus-corona/

8. Zhong B L, Luo W, Li HM, Zhang QQ, Liu XG, Li WT, et al. Knowledge, attitudes, and practices towards Covid-19 among Chinese residents during the rapid rise period of the Covid-19 outbreak: A quick online cross-sectional survey. Int J Biol Sci. 2020;16(10):1745-52.

9. Zhang M, Zhou M, Tang F, Wang Y, Nie H, Zhang $\mathrm{L}$, et al. Knowledge, attitude, and practice regarding Covid-19 among healthcare workers in 
Henan, China. J Hosp Infect. 2020; 105 (2): 183-7.

10. Rahman A, Sathi NJ. Knowledge, Attitude, and Preventive Practices toward Covid-19 among Bangladeshi Internet Users. Electron J Gen Med. 2020;17(5):1-5.

11. Chirwa GC. Socio-economic Inequality in Comprehensive Knowledge about HIV in Malawi. Malawi Med J. 2019;31:104-11.

12. Hossain MA, Jahid IK, Hossain A, Walton LM, Uddin Z, Haque $O$, et al. Knowledge, attitude, and fear of Covid-19 during the rapid rise periode in Bangladesh. PLoS One. 2020;15(9):1-7.

13. Azlan AA, Hamzah MR, Sern TJ, Ayub SH, Mohamad E. Public knowledge, attitude and practices towards Covid-19: Cross-sectional study in Malaysia. PLoS One. 2020;15(5):1-5.

14. Jiang L, Ng IHL, Hou Y, Li D, Tan LWL, Ho HJA. Infectious disease transmission: survey of contacts between hospital-based healthcare workers and working adults from the general population. J Hosp Infect. 2018;98:404-41.

15. Huynh G, Nguyen TNH, Tran VK, Vo KN, Vo VT, Pham LA. Knowledge and attitude toward Covid-19 among healthcare workers at District 2 Hospital, Ho Chi Minh City. Asian Pac J Trop Med. 2020;13(6):260-5.

16. Yanti M, Mulyadi E, Wahiduddin, Novika RGH, Arina YMD, Martani NS, Nawan. Community Knowledge, Attitudes, and Behaviour Towards Social Distancing Policy As A Means of Preventing Transmision of Covid-19 In Indonesia. Indonesian Journal of Health Administration. 2020; 8(1):4-14.

17. Azlan AA, Hamzah MR, Sern TJ, Ayub SH, Mohamad E. Public Knowledge, attitudes and practices towards Covid-19: A cross-sectional study in Malaysia. PLoS One. 2020; 15(5) e0233668.

18. Zhong BL, Luo W, Li HM, Zhang QQ, Liu XG, Li WT. Knowledge, attitudes and practices towards Covid-19 among Chinese residents during the rapid rise period of the Covid-19 outbreak: A quick online cross-sectional survey. Int $\mathrm{J}$ Biol Sci. 2020;16(10):1745-52.

19. Chalise HN. South Asia is more vulnerable to Covid-19 pandemic. Arch Psychiatr Ment Health. 2020;4:046-7.

20. Nooh HZ, Alshammary RH, Alenezy JM, Alrowaili $\mathrm{NH}$, Alsharari AJ, Alenzi NM. Public awareness of coronavirus in Al-Jouf region, Saudi Arabia. $J$ Public Health. 2020.13(1):1-8.

21. World Health Organization (WHO). Shortage of personal protective equipment endangering health workers worldwide. Geneva: WHO; 2020 [diakses 2020 August 24]. Tersedia dari https://www.who.int/news/item/03-03-2020shortage-of-personal-protective-equipmentendangering-health-workers-worldwide

22. Abuhammad S. Parents knowledge and attitude towards Covid-19 in children: A Jordanian Study. Int J Clin Pract. 2020.14(1):1-6

23. Barley E, Lawson V. Using health psychology to help patients: Theories of behaviour change. $\mathrm{Br} J$ Nurs. 2020;25(16):924-7.

24. Al-Mohrej OA, Al-Shirian SD, Al-Otaibi SK, Tamim HM, Masuadi EM, Fakhoury HM. Is the Saudi public aware of Middle East respiratory syndrome? J Infect Public Health. 2016;9(3):25966. 